\title{
Improving Water Use Efficiency through Reduced Irrigation for Sustainable Cotton Production
}

\author{
Hafiz Shahzad Ahmad 1, Muhammad Imran 1,*(D), Fiaz Ahmad 2 (D), Shah Rukh 1,3, Rao Muhammad Ikram 4 , \\ Hafiz Muhammad Rafique ${ }^{5}$, Zafar Iqbal ${ }^{6}$, Abdulaziz Abdullah Alsahli ${ }^{7}$ (D), Mohammed Nasser Alyemeni ${ }^{7}$, \\ Shafaqat Ali ${ }^{8,9, *(D)}$ and Tanveer-ul-Haq ${ }^{1}$
}

1 Department of Soil and Environmental Sciences, MNS University of Agriculture, Multan 60000, Pakistan; ahmedshahzad444@gmail.com (H.S.A.); shahrukh.nceg@uop.edu.pk (S.R.); tanveer.ulhaq@mnsuam.edu.pk (T.-u.-H.)

2 Physiology Section, Central Cotton Research Institute, Multan 60000, Pakistan; fiazdrccri@gmail.com

3 National Centre of Excellence in Geology, University of Peshawar Pakistan, Peshawar 25120, Pakistan

4 Department of Agronomy, MNS University of Agriculture, Multan 60000, Pakistan; rao.ikram@mnsuam.edu.pk

5 Pesticide Quality Control Laboratory, Multan 60000, Pakistan; rafiqqais@gmail.com

6 Soil and Water Testing Laboratory Mianwali, Mianwali 42200, Pakistan; zafariqbal3545@gmail.com

7 Department of Botany and Microbiology, College of Science, King Saud University, Riyadh 11451, Saudi Arabia; aalshenaifi@ksu.edu.sa (A.A.A.); mnyemeni@ksu.edu.sa (M.N.A.)

8 Department of Environmental Sciences, Government College University, Faisalabad 38000, Pakistan

9 Department of Biological Sciences and Technology, China Medical University, Taichung 40402, Taiwan

* Correspondence: m.imran@mnsuam.edu.pk (M.I.); shafaqataligill@gcuf.edu.pk (S.A.)

check for updates

Citation: Ahmad, H.S.; Imran, M.; Ahmad, F.; Rukh, S.; Ikram, R.M.; Rafique, H.M.; Iqbal, Z.; Alsahli, A.A.; Alyemeni, M.N.; Ali, S.; et al. Improving Water Use Efficiency through Reduced Irrigation for Sustainable Cotton Production. Sustainability 2021, 13, 4044. https://doi.org/10.3390/su13074044

Academic Editor: Azhar Abbas

Received: 31 December 2020

Accepted: 23 February 2021

Published: 6 April 2021

Publisher's Note: MDPI stays neutral with regard to jurisdictional claims in published maps and institutional affiliations.

Copyright: (c) 2021 by the authors. Licensee MDPI, Basel, Switzerland. This article is an open access article distributed under the terms and conditions of the Creative Commons Attribution (CC BY) license (https:// creativecommons.org/licenses/by/ $4.0 /)$.
Abstract: The socio-economic development of a country is highly dependent on water availability. Nowadays, increasing water scarcity is a major global challenge. Continuing improvements in wateruse efficiency are essential for cotton production sustainability. Reduced irrigation in cotton could be a solution to water shortage in the arid climate without compromising the cotton yield. Therefore, a two-year field study was conducted to assess the effect of two levels of irrigation i.e., 50\% and 100\% of available water content (AWC) on the yield of four cotton genotypes (CIM-678, CIM-343, CRIS-613, and CYTO-510). The maximum seed cotton yield was observed in CIM-678, which was 2.31 and $2.46 \mathrm{Mg} \mathrm{ha}^{-1}$ under 100\% AWC during 2018 and 2019, respectively, and was non-significantly reduced by 7.7 and $8.94 \%$, owing to deficit irrigation. The maximum water use efficiency (WUE) of 0.55 and $0.64 \mathrm{Kg} \mathrm{ha}^{-1} \mathrm{~mm}^{-1}$ was observed under 50\% AWC in CIM-678, which was significantly higher than WUE at $100 \%$ AWC during both years. Leaf area index and physiological parameters such as photosynthesis rate, transpiration rate, and stomatal conductance were not significantly affected by deficit irrigation. So, it was concluded that the reduced irrigation technique performed well without significant yield loss, improve WUE, and saved $37 \mathrm{~cm}$ of water that could be used for other crops or to increase the area of the cotton crop.

Keywords: available water contents (AWC); water use efficiency (WUE); irrigation; time-domain refractometry (TDR); soil moisture

\section{Introduction}

Water is an important element that plays a major role in crop production, as it maintains nutrient availability and leaf turgidity in plants. The entire world is water-dependent and water shortage is one of the crucial global issues. [1]. Pakistan is also among the countries that are at risk of water shortage due to climate change and its geographic location. Water resources in the country are being depleted rapidly [2]. There is a dire need to quantify the crop water requirement according to the growth stage of the crop and the type of soil [3]. The primary aim of reduced irrigation is to minimize the loss of water and increase crop water use efficiency (WUE). The relationship between the amount of 
water applied and crop yield is referred to as WUE [4]. Over or under irrigation results in low crop yield and loss of water. Irrigation scheduling is necessary to know the optimal amount of irrigation required for crops.

Cotton is a significant cash crop, also known as sliver fiber in Pakistan [5], which provides raw materials to textile sectors due to its distinctive quality [1]. Pakistan ranks 5th in the world as the largest textile producer after India, China, the United States, and Brazil. At present, cotton production in the country is 11.9 million bales and it amounts to 5.5 and $1.5 \%$ in agriculture and total Gross Domestic Product (GDP), respectively. During 2017, the cotton yield was recorded $11.8 \%$ higher than the 2016 production of 10.7 million bales. The area under cotton cultivation was increased by $8.4 \%$ during 2017 compared to 2016 . The current area under cotton cultivation is increasing with low production per unit area which cannot fulfill even the indigenous growing population's requirements. The share of cotton consumption is $2.6 \%$ in global water usage [6] as it consumes almost 10,000 L of water to produce one kilogram of cotton fabric, which means it takes about $8000 \mathrm{~L}$ of water for a pair of cotton jeans. There is a dire need to understand the pressure of cotton production on freshwater resources i.e., assessing how much water is used in the production of cotton related to an area of land. Since it may not be possible to extend the current area under cotton cultivation as it is already occupied by other significant crops such as wheat, rice, corn, and sugar cane, therefore, increasing the yield of cotton from the existing cultivated area is a more feasible option.

There are several factors affecting cotton productivity such as the use of low-quality seed resulting in poor germination, low seed rate, low plant population, poor management practices, conventional sowing methods, insect pests attack, improper nutrition, water stress, and use of inferior cotton genotypes; however, the two key factors that can have a significant impact on cotton production are genotype and water availability. Cotton yield can be optimized with appropriate genotype and optimal use of irrigation water; however, there is a severe shortage of irrigation water and high-yielding cotton genotypes. In agriculture, the current water availability scenario highlights the effective use of water resources [7]. Cotton is a tropical seasonal crop that needs a limited supply of water from either irrigation or rainfall for a successful production. Globally, scientists are working on the optimization of cotton production by rational use of limited available water [4,8-10]. One of the main problems for farmers is the use of insufficient water to increase crop efficiency [11]. By using the finest irrigation management procedures, WUE can be enhanced. It is necessary to explore effective agronomic exercise with the ability to increase WUE and crop yields [12]. Due to the importance of the cotton crop, efforts have been made to improve cotton yield and enhance resource use efficiency. In Pakistan, WUE is very low as compared to the rest of the world, where water-saving agriculture is focused on improving crop WUE [7].

Since the study area, Multan is an arid region and has limited rainfall in addition to the low organic matter status of the soil, high-yielding genotypes grown with irrigation management could be a viable option for efficient use of inadequate irrigation water. Moreover, drought-tolerant cotton genotypes should be produced for being well fit in the cotton belt. The present study focuses on the improvement of water productivity of cotton with the objectives, (i) to assess the actual water requirement for cotton crop in arid climate and (ii) to improve cotton yield and WUE through reduced irrigation.

\section{Materials and Methods}

\subsection{Experimental Site}

Two years of field experiments were conducted over the growing period of 2018 and 2019 at the research farm of Central Cotton Research Institute (CCRI), Multan ( $30^{\circ} 12 \mathrm{~N}$, $71^{\circ} 28 \mathrm{E}$, and $123 \mathrm{~m}$ altitude). The soil used in the trial belonged to the Sultanpur series. It was coarse silty, hyperthermic Typic Camborthids, permeable, friable, moderately calcareous, and weakly structured. The soil was developed in the Indus delta of sub-recent flood plains with an arid climate [13]. The soil was silt loam composed of less than $1 \%$ 
organic matter, $0.042 \%$ total $\mathrm{N}, 8.9 \mathrm{mg} \mathrm{kg}^{-1}$ available $\mathrm{P}, 130 \mathrm{mg} \mathrm{kg}^{-1}$ extractable $\mathrm{K}$, and electrical conductivity was $3.69 \mathrm{dSm}^{-1}$ at the depth of $0-40 \mathrm{~cm}$. Groundwater was used for agricultural irrigation $\left(\mathrm{EC}=1.1 \mathrm{dSm}^{-1}\right)$. Two years' daily weather data was collected from the weather station installed at CCRI from May to November. The maximum and minimum temperature and relative humidity are shown in Figure 1.

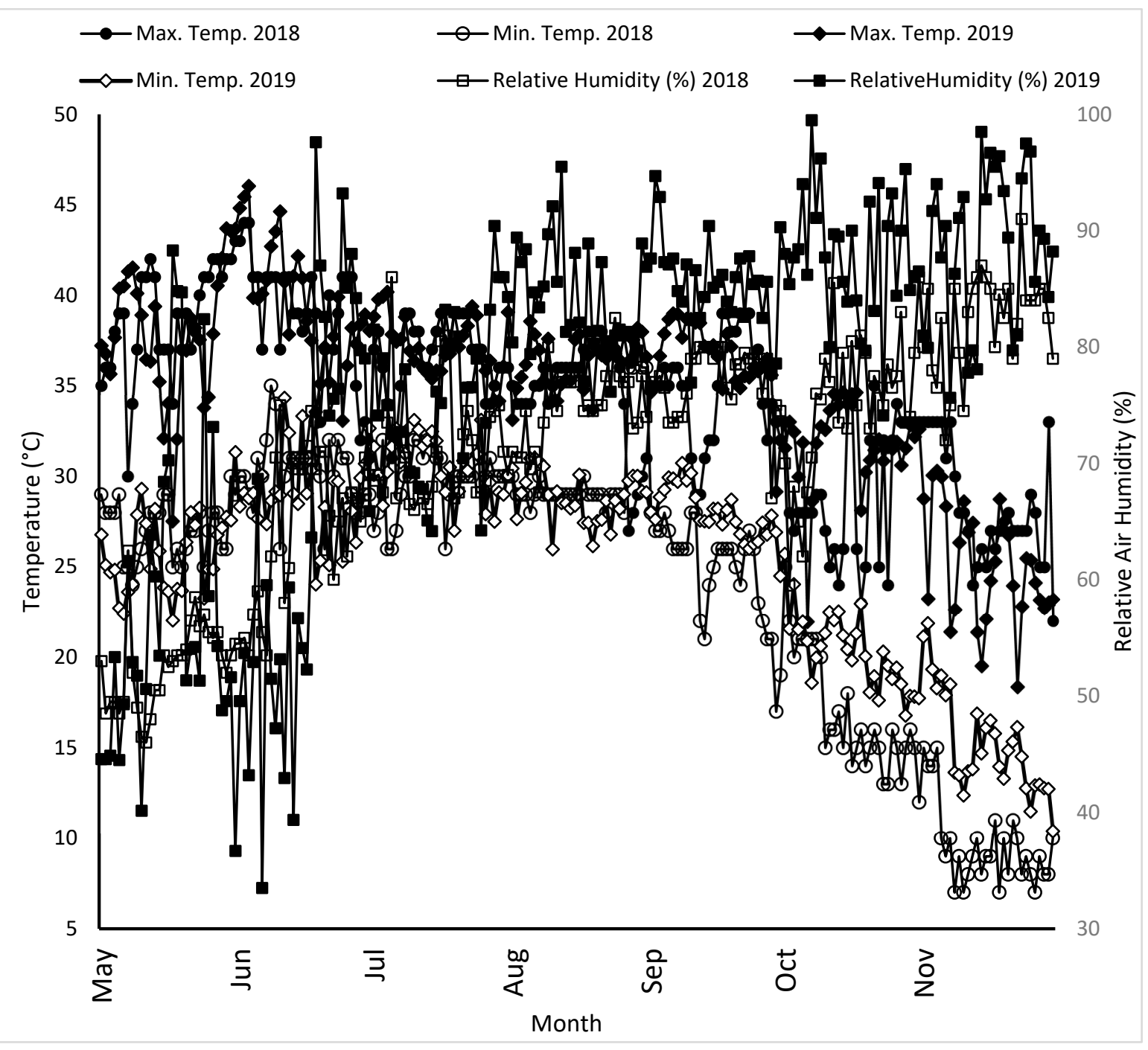

Figure 1. Weather data collected daily during crop growing season.

\subsection{Experimental Design}

The experimental layout design in the study was a split-plot design with factorial arrangements i.e., main plots consisting of two irrigation levels such as 50 and 100\% available water contents (AWC) and subplots containing four cotton genotypes such as CIM-343, CYTO-510, CRIS-613, and CIM-678. The irrigation water applied throughout the growth period (2018 and 2019) was based on the measurement of the soil moisture content in the $0-40 \mathrm{~cm}$ soil horizon using a time-domain refractometer (TDR-200). The TDR was calibrated using a direct method for soil moisture determination. The soil moisture content was measured from 0-10, 10-20, 20-30, and 30-40 cm at a 2-day interval and the irrigation was applied to maintain 50 and 100\% AWC in the root zone when it reached near the permanent wilting point (PWP). Each subplot was $15 \mathrm{~m}$ long and $3 \mathrm{~m}$ wide, for a total plot size of $45 \mathrm{~m}^{2}$. The recommended dose of NPK (150-60-60 Kg) was applied, P 
and $\mathrm{K}$ were applied at the time of sowing, and $\mathrm{N}$ was applied in split doses. All the other agronomic and plant protection measures were adopted accordingly.

\subsection{Data Collections}

\subsubsection{Actual Evapotranspiration}

By using the soil water balance equation, the actual evapotranspiration $\left(\mathrm{Et}_{\mathrm{a}}\right)$ was calculated $[14,15]$

$$
\mathrm{ET}_{\mathrm{a}}=(\mathrm{I}+\mathrm{p})-\Delta \mathrm{S},
$$

where I $(\mathrm{mm})$ represents the irrigation, $\mathrm{p}(\mathrm{mm})$ represents the precipitation, and change in root zone storage is denoted by $\Delta \mathrm{S}(\mathrm{mm})$.

The reference evapotranspiration was calculated by the penman monteith equation [16] shown in Figure 2.

$$
\mathrm{ET}_{0}=\frac{0.408 \Delta\left(\mathrm{R}_{\mathrm{n}}-\mathrm{G}\right)+\gamma \frac{900}{\mathrm{~T}_{\text {mean }}+273} \mathrm{u}_{2}\left(\mathrm{e}_{\mathrm{s}}-\mathrm{e}_{\mathrm{a}}\right)}{\Delta+\gamma\left(1+0.34 \mathrm{u}_{2}\right)},
$$

where $\mathrm{ET}_{0}$ is reference evapotranspiration $\left(\mathrm{mm}^{-1 a y}{ }^{-1}\right), \mathrm{R}_{\mathrm{n}}$ is net radiation as denoted by $\left(\mathrm{MJ} \mathrm{m}^{-2}\right.$ day $\left.^{-1}\right), \mathrm{G}$ is the density of soil heat flux $\left(\mathrm{MJ} \mathrm{m}^{-2}\right.$ day $\left.^{-1}\right), \gamma$ is psychrometric constant $\left(\mathrm{kPa}^{\circ} \mathrm{C}^{-1}\right), \mathrm{T}_{\text {mean }}$ is the average daily temperature $\left({ }^{\circ} \mathrm{C}\right), \mathrm{u}_{2}$ is wind speed $\left(\mathrm{m} \mathrm{s}^{-1}\right)$, $\mathrm{e}_{\mathrm{a}}$ is actual vapor pressure $(\mathrm{kPa}), \mathrm{e}_{\mathrm{s}}$ is saturation vapor pressure $(\mathrm{kPa})$, and $\Delta$ is the slope of the vapor pressure $\left(\mathrm{kPa}^{\circ} \mathrm{C}^{-1}\right)$.

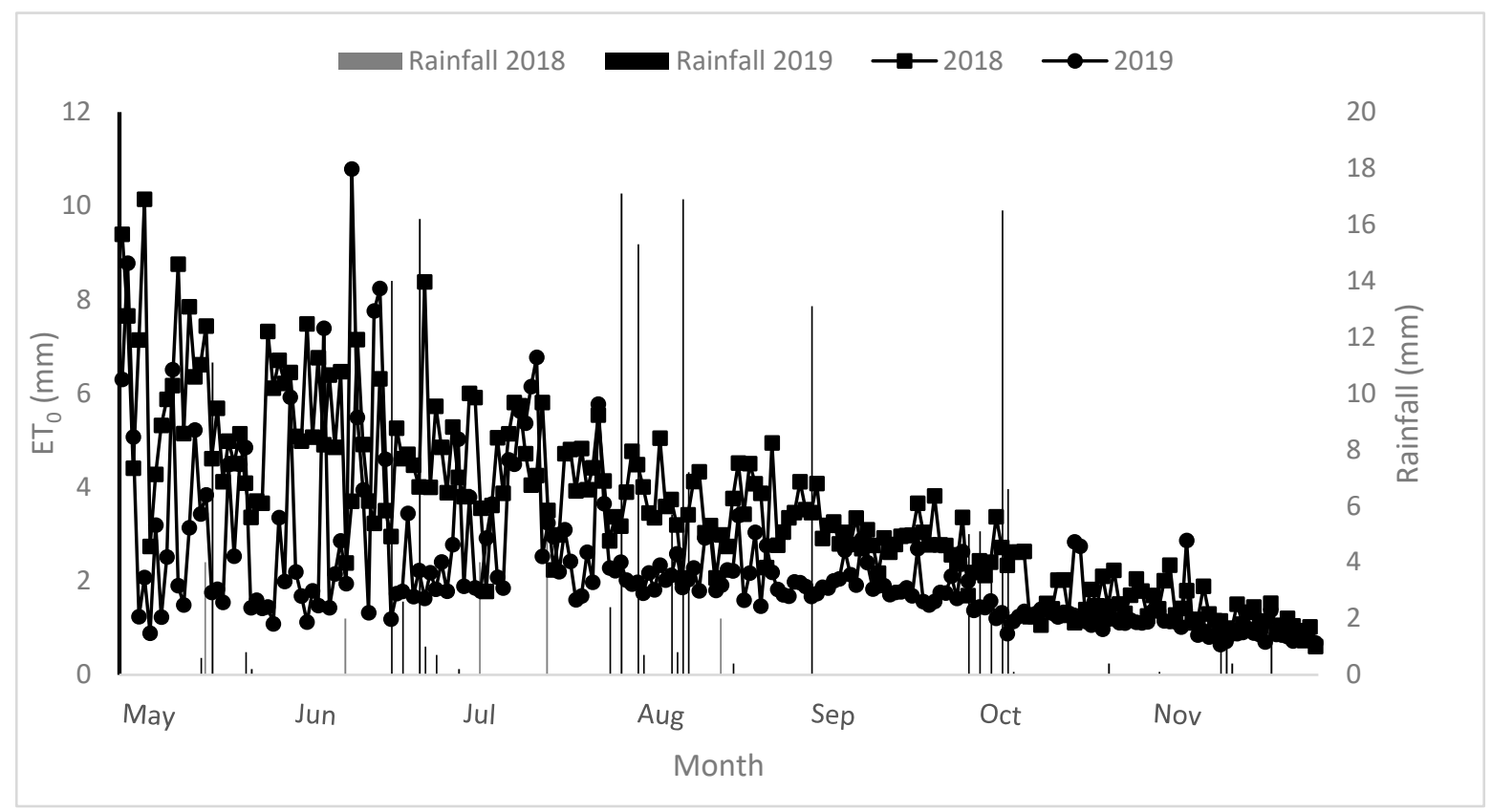

Figure 2. Shows monthly $\mathrm{ET}_{0}$ data during crop growing season.

\subsubsection{Water Use Efficiency}

The WUE was calculated by using the following equation [17]

$$
\mathrm{WUE}=\frac{\mathrm{Y}}{\mathrm{ET}_{\mathrm{a}}}
$$

where WUE is water use efficiency $\left(\mathrm{kg} \mathrm{m}^{-3} \mathrm{ha}^{-1}\right), \mathrm{Y}$ is yield $\left(\mathrm{kg} \mathrm{ha}^{-1}\right)$, and $\mathrm{ET}_{\mathrm{a}}$ is actual evapotranspiration (mm). 


\subsection{Soil Physico-Chemical Parameters}

The measured and estimated parameters of soil are presented in Table 1. Soil texture was calculated by the hydrometer method, organic matter was measured by the Walkley Black method, EC and $\mathrm{pH}$ were measured by soil extraction and NPK was measured by digestion. The bulk density of soil was calculated by taking the soil samples with the help of core at the depth of 0-10, 10-20, and 30-40 cm [18]. The hydraulic conductivity and water retention curve parameters were estimated using the Saxton and Rawls methods [19].

Table 1. Measured soil physical and hydraulic parameters in the four main horizons of the experimental site.

\begin{tabular}{|c|c|c|c|c|c|c|c|c|c|c|}
\hline \multirow{3}{*}{$\begin{array}{c}\text { Depth (cm) } \\
0-10\end{array}$} & \multicolumn{3}{|c|}{ Particle Fractions (\%) } & \multirow{3}{*}{$\begin{array}{c}\text { B.D. } \\
\left(\mathrm{Mg} \mathrm{m}^{-3}\right) \\
1.32 \pm 0.13\end{array}$} & \multirow[t]{2}{*}{${ }^{*} \theta_{\mathrm{s}}$} & ${ }^{*} \theta_{\mathrm{FC}}$ & ${ }^{*} \theta_{\mathrm{PWP}}$ & ${ }^{*} \theta_{\mathrm{AWC}}$ & \multirow{3}{*}{$\begin{array}{c}{ }^{*} \mathbf{K}_{\mathrm{fs}} \\
\text { cm day }^{-1} \\
12.23 \pm 2.06\end{array}$} & \multirow{3}{*}{$\begin{array}{c}\text { SOM } \\
\text { (\%) } \\
0.62 \pm 0.4\end{array}$} \\
\hline & \multirow{2}{*}{$\begin{array}{c}\text { Sand } \\
19.83 \pm 0.12\end{array}$} & \multirow{2}{*}{$\begin{array}{c}\text { Silt } \\
56.58 \pm 0.10\end{array}$} & \multirow{2}{*}{$\begin{array}{c}\text { Clay } \\
23.59 \pm 0.13\end{array}$} & & & \multicolumn{2}{|c|}{$\mathrm{cm}^{3} \mathrm{~cm}^{-3}$} & & & \\
\hline & & & & & $0.43 \pm 0.021$ & $0.318 \pm 0.032$ & $0.145 \pm 0.013$ & $0.248 \pm 0.014$ & & \\
\hline $10-20$ & $20.23 \pm 0.13$ & $55.32 \pm 0.15$ & $24.45 \pm 0.12$ & $1.37 \pm 0.08$ & $0.43 \pm 0.035$ & $0.319 \pm 0.021$ & $0.150 \pm 0.023$ & $0.242 \pm 0.013$ & $11.58 \pm 3.42$ & $0.48 \pm 0.3$ \\
\hline $20-30$ & $20.68 \pm 0.18$ & $54.71 \pm 0.21$ & $24.61 \pm 0.23$ & $1.43 \pm 0.04$ & $0.42 \pm 0.051$ & $0.323 \pm 0.092$ & $0.154 \pm 0.016$ & $0.242 \pm 0.011$ & $11.58 \pm 3.67$ & $0.41 \pm 0.6$ \\
\hline $30-40$ & $21.56 \pm 0.17$ & $54.23 \pm 0.24$ & $24.21 \pm 0.19$ & $1.45 \pm 0.03$ & $0.41 \pm 0.012$ & $0.328 \pm 0.021$ & $0.156 \pm 0.017$ & $0.139 \pm 0.012$ & $10.97 \pm 2.19$ & $0.26 \pm 0.3$ \\
\hline
\end{tabular}

B.D.- soil bulk density, $\theta_{\mathrm{S}}$ - saturated water content, $\theta_{\mathrm{FC}}$ - water content at field capacity, $\theta_{\mathrm{PWP}}$-water content at the permanent wilting point, $\theta_{\mathrm{AWC}}$ - available water content, $\mathrm{K}_{\mathrm{fs}}$ - field saturated hydraulic conductivity, $\mathrm{SOM}$ - soil organic matter, * indicates the estimated parameter.

\subsection{Leaf Area Index (LAI) and Seed Cotton Yield}

The leaf area was obtained from three randomly selected leaves (top, middle, and bottom leaf) from three randomly selected plants per replication per treatment using an area measurement system (Delta-T-Devices LTD, Sunwell Cambridge, England). The LAI was calculated with the following formula [20].

$$
\text { LAI }=\frac{\text { Leaf area }}{\text { Ground area }}
$$

In the end yield ( $\mathrm{Mg} / \mathrm{ha})$ was also compared among all the treatments.

\subsection{Gas Exchange Parameters}

The data of gas exchange parameters of intervals of 60, 105, and 130 days after sowing was recorded at the time of 10:00 a.m.-12:00 p.m. from the top of the fourth fully expanded leaf. These were measured with the help of an InfraRed Gas Analyzer (Photosynthetic meter, Model CI-340, Handheld Photosynthetic system, CID-Bioscience) [21]. The observations were taken after the irrigation when the field was fully saturated. The following parameters were measured:

Net photosynthesis $\left(P N=\mu \mathrm{mol} \mathrm{CO} \mathrm{CO}^{-2} \mathrm{~S}^{-1}\right)$

Transpiration rate $\left(E=\mathrm{mmol} \mathrm{H}_{2} \mathrm{O} \mathrm{m}^{-2} \mathrm{~S}^{-1}\right)$

Stomatal conductance (gs $=\mathrm{mmol} \mathrm{CO}_{2} \mathrm{~m}^{-2} \mathrm{~S}^{-1}$ )

\subsection{Statistical Analysis}

The data collected were subjected to ANOVA using randomized complete block design with split plot arrangement and means were compared by least significance difference test (LSD) at 5\% level of probability by using statsistix 8.1 software [22].

\section{Results}

\subsection{Soil Water Storage and Actual Evapotranspiration}

The soil water storage and evapotranspiration data at 50 and 100\% AWC in all genotypes are shown in Figure 3. No significant difference was observed in treatments regarding soil water storage in both years. It showed that irrigation at the time of sowing resulted in storage above field capacity (FC). After germination when plant roots were grown deeper, it reduced the soil storage below FC and up to the permanent wilting point (PWP). Soil water storage showed more depletion of water at 50\% AWC as compared to 100\% AWC in all genotypes. The highest $\mathrm{ET}_{\mathrm{a}}$ was observed in 100\% AWC as compared to 50\% AWC treatment in all genotypes which was statistically significant (Figure 3). The increase in $\mathrm{ET}_{\mathrm{a}}$ might be due to more water loss through evaporation which is the main component of $\mathrm{ET}_{\mathrm{a}}$. 


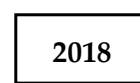

CIM-678

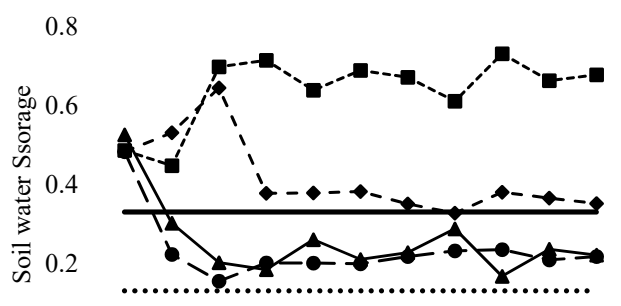

0.0

CIM-343

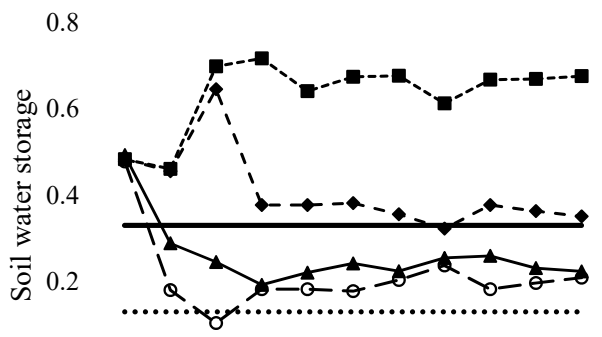

0.0

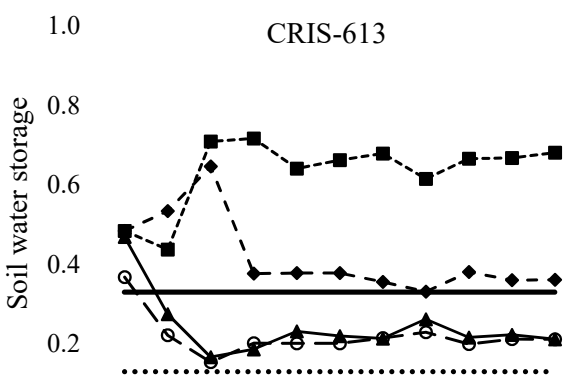

0.0

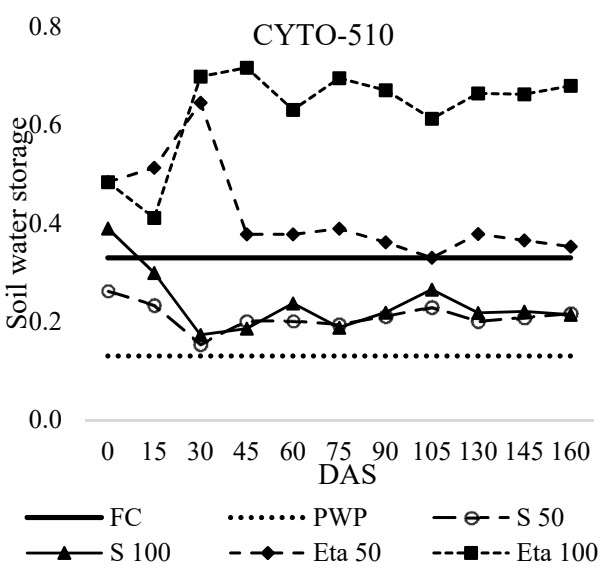

\section{9}

CIM-678

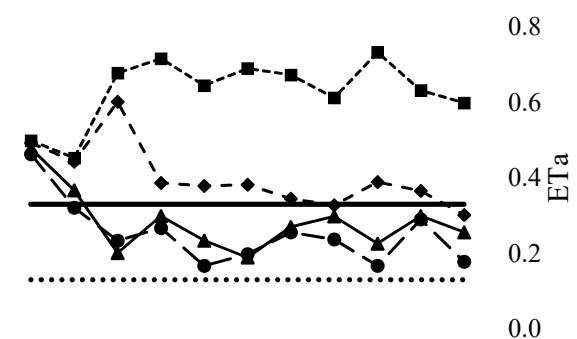

CIM-343

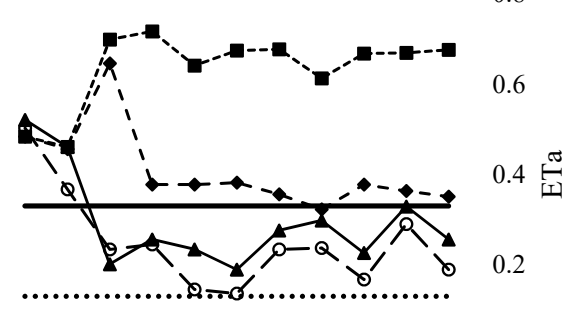

0.0
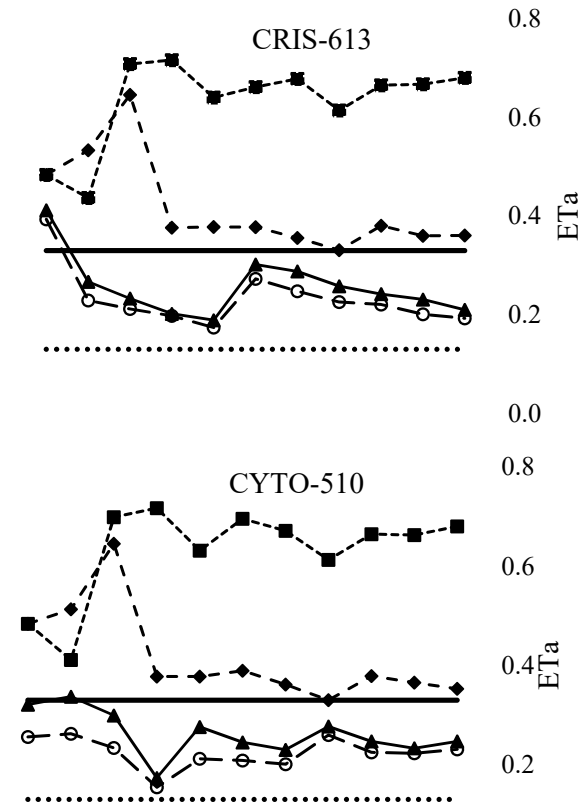

0.0

$\begin{array}{llllllll}0 & 15 & 30 & 45 & 60 & 75 & 90 & 105130145160\end{array}$

$\begin{array}{lll} & \text { DAS } & \\ \longrightarrow \text { FC } & \cdots \cdots \cdot \text { PWP } & -\theta-\text { S } 50 \\ \text { S } 100 & -\rightarrow-\text { Eta } 50 & --\rightarrow-\cdot \text { Eta } 100\end{array}$

Figure 3. Effect of reduced irrigation on soil water storage and actual evapotranspiration $\left(\mathrm{ET}_{\mathrm{a}}\right)$ during 2018 and 2019 (DAS—days after sowing).

\subsection{Leaf Area Index}

It was observed that LAI increased with the days after sowing (DAS) in 100\% AWC as compared to 50\% AWC during the whole growing period in both years (2018 and 2019) but it was statistically at par in both treatments. This might be due to the availability of 
moisture in the root zone and it was observed that when water was applied at the rate of $50 \%$ of AWC there was no water stress. The water stress started when soil moisture contents fell below $40 \%$ of AWC. The maximum LAI was observed in CYTO-510 in both years as compared to other genotypes (Figure 4).
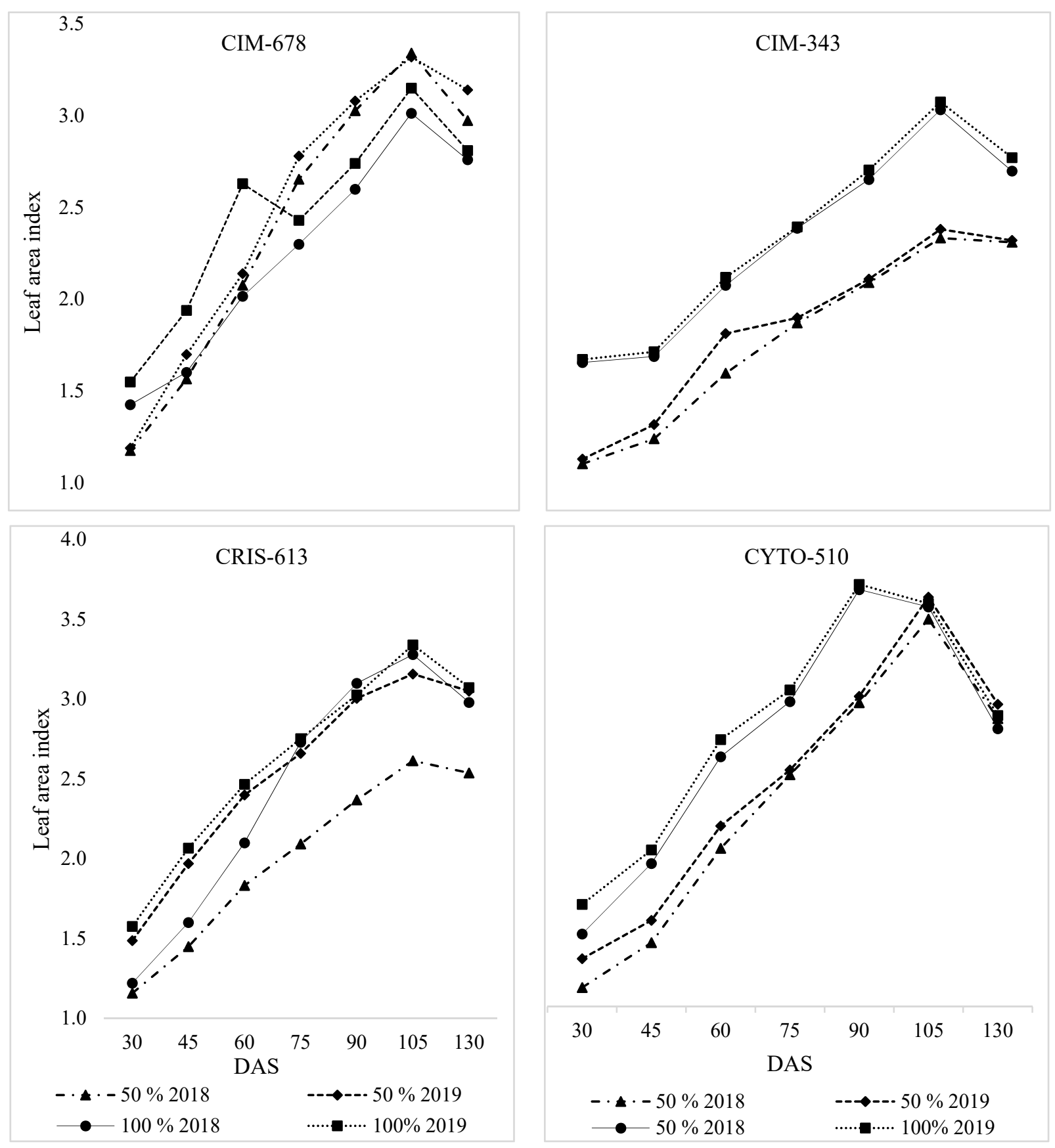

Figure 4. Effect of reduced irrigation on leaf area index of different varieties of cotton (DAS—days after sowing).

\subsection{Seed Cotton Yield}

In the case of cotton seed yield irrigation, varieties and their interaction showed non-significant $(p \geq 0.05)$ results (Figure 5). The maximum yield was observed in CIM-678, which was 2.31 and $2.46 \mathrm{Mg} \mathrm{ha}^{-1}$ under $100 \%$ AWC while 7.7 and $8.94 \%$ reduction in yield was observed where $50 \%$ AWC was maintained throughout the growing period in both years 2018 and 2019 respectively (Figure 5). This reduction in yield was statistically 
non-significant as compared to $100 \%$ AWC. A similar trend was observed in all genotypes under 50 and $100 \%$ AWC.

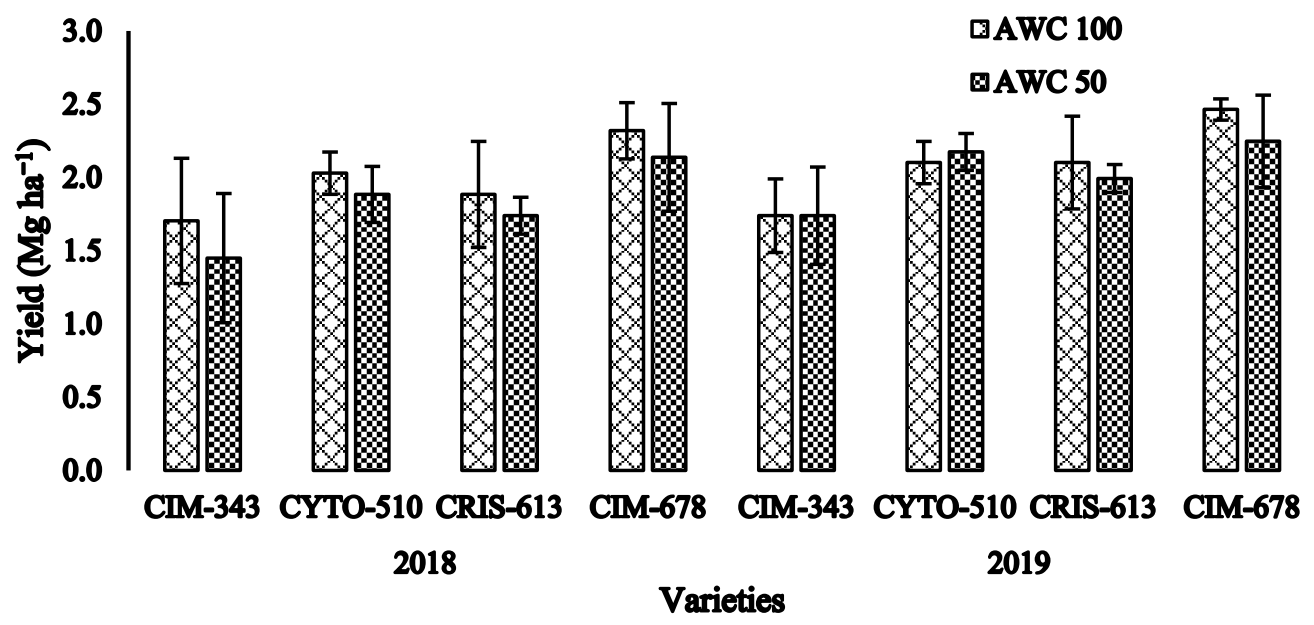

Figure 5. Effect of reduced irrigation on seed cotton yield (AWC-available water content).

\subsection{Water Use Efficiency}

The WUE data showed statistically significant $(p>0.05)$ results for irrigation while varieties and their interaction were statistically non-significant. Overall, WUE was higher in all the genotypes under 50\% AWC (Figure 6). The highest WUE under 50\% AWC might be due to reduced water losses from the field as evaporation losses. CIM-678 showed maximum WUE 0.54 and $0.64 \mathrm{Kg} \mathrm{m}^{-3} \mathrm{ha}^{-1}$ under 50\% AWC in 2018 and 2019 respectively. The minimum WUE was observed in CIM-343 in 50\% and 100\% AWC in 2018 and 2019, respectively.

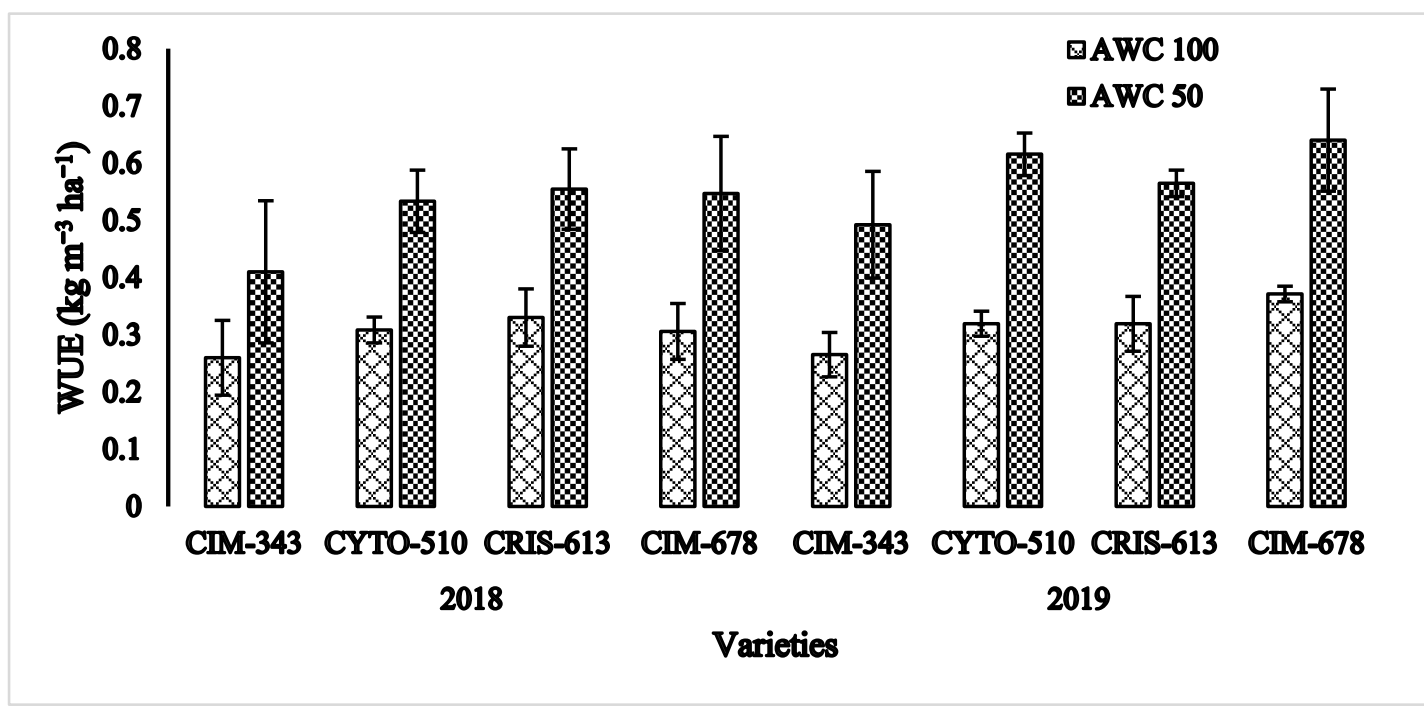

Figure 6. Effect of reduced irrigation on water use efficiency (AWC-available water content).

\subsection{Physiological Parameters \\ 3.5.1. Net Photosynthesis Rate}

It was observed that in the first 105 DAS the photosynthetic rate of plants at $50 \%$ AWC was higher as compared to $100 \%$ AWC maintained throughout the growing period in both years. The CIM-343 showed the maximum photosynthesis rate in 100\% AWC but CRIS-613 and CIM-678 showed a positive response in 50\% AWC as compared to 100\% AWC. 


\subsubsection{Transpiration Rate}

It was observed that the transpiration rate was maximum at $100 \%$ AWC as compared to $50 \%$ AWC. At first 60 DAS, the transpiration rate in CIM-343 was maximum in $100 \%$ AWC while all the other varieties showed minimum transpiration rate at both AWC. At 105 DAS there was no significant difference in both treatments. At 130 DAS the maximum transpiration rate was observed in 50\% AWC treatment. As the DAS increased, the rate of transpiration also increased because the plants utilized more water for different physiological processes (Figure 7).
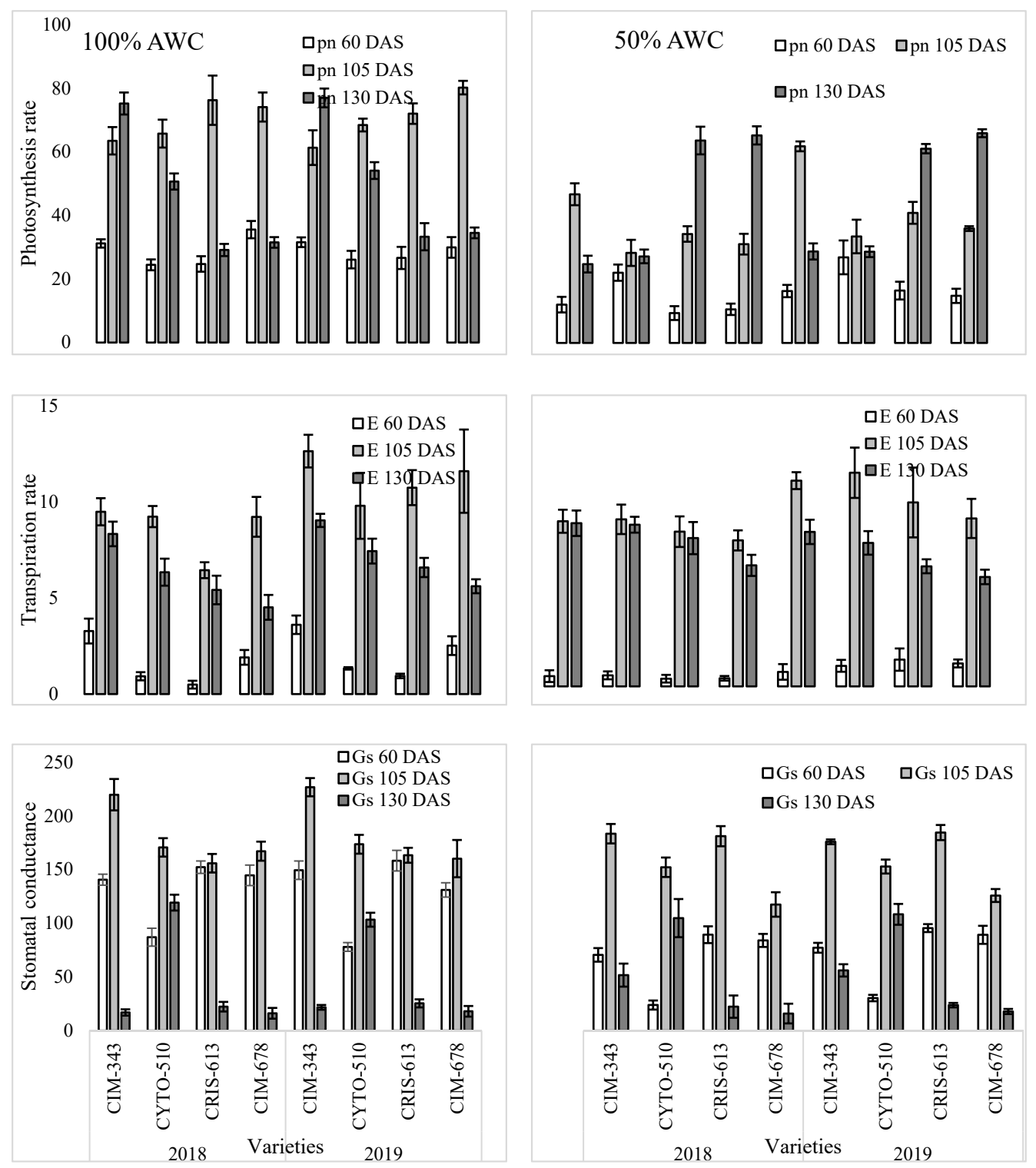

Figure 7. Effect of reduced irrigation on gas exchange parameters of cotton (pn-net photosynthesis rate, E-transpiration rate, Gs—stomatal conductance, and DAS-days after sowing).

\subsubsection{Stomatal Conductance}

The CRIS-613 showed extreme stomatal conductance in 100\% AWC while the least stomatal conductance was measured in CYTO-510 in the same treatment. In the case of $50 \%$ AWC, extreme stomatal conductance was shown by CRIS-613, and the minimum was observed in CYTO-510. At 105 DAS the stomatal conductance was maximum in CIM-343 in the treatment where $80 \%$ AWC was maintained. This observation was made before irrigation, so plants showed maximum stomatal conductance. At 130 DAS stomatal 
conductance in CYTO-510 was higher at 100\% AWC as compared to other varieties in the same treatment. While in 50\% AWC stomatal conductance was maximum in CYTO-510 as compared to other varieties. Except for CYTO-510, all other varieties showed the highest stomatal conductance at 60 DAS and 105 DAS. In reduced irrigation at 105 DAS of the crop, the stomatal conductance was maximum and was equal to full irrigation because of the fruiting stage of the crop.

\section{Discussion}

Accumulation of biomass is strongly related to photosynthesis and light interception (leaf area index) [20]. Under a water deficit, aboveground growth is more impaired, as compared to belowground. Under these conditions, leaf area is often reduced [20], which leads to decreased yield [21,23]. Our results are in agreement with Fereres and Soriano [24] who reported that deficit irrigation reduced water usage without affecting the crop yield and quality. Similarly, Ertek and Kanber [25] reported that there was no effect on yield by using reduced irrigation in the form of drip irrigation. Basal et al. [26] also showed that applying 75\% irrigation water did not affect cotton yield as compared to full irrigation.

The WUE was increased by 50\% AWC, probably because of the reduced water losses in the form of both evapotranspiration and drainage below the root zone. So, there was no yield benefit in the application of water more than 50\% AWC. As discussed both photosynthesis and leaf area index (light interception) are major yield components [27]. The underwater stress, the former is less sensitive as compared to the latter [28]. When the water supply is restored, both parameters often recover [29]. Reduction in photosynthesis is generally due to stomatal closure in response to reduced irrigation.

At the onset of the photoperiod, photosynthesis was at the highest rate because of low vapor pressure deficit and improved water status owing to the scot period. No statistically significant difference in photosynthesis rate was observed in the whole crop cycle between the two irrigation regimes.

Sustainable cotton production requires intelligent farming. For example, it involves efficient resource use, timely planting, and optimal irrigation by using the respective methods. To achieve the maximum crop per drop and increase yield, a strategy in the direction of improving farm-level water management ought to be developed. This involves the strengthening of the engagement between farmers and partners located in the river basins, where cotton cultivation takes place. Since significant yield variations between farms located in the same areas are evident, the above-mentioned strategy may incorporate information and knowledge sharing, as well as training.

\section{Conclusions}

Our findings suggest that yield, leaf area index, and physiological parameters were not affected by 50\% AWC, whereas WUE was significantly enhanced. Therefore, it can be suggested that the application of reduced irrigation maintains the yield in arid and semiarid areas. As cotton is a hot seasonal and sensitive crop that requires precise application of irrigation water, the results of this study will help in mitigating the water crises especially in cotton-growing areas for sustainable crop production.

Author Contributions: Conceptualization, M.I., H.M.R., A.A.A., M.N.A. and S.A.; Data curation, H.S.A., F.A., S.R., R.M.I. and Z.I.; Formal analysis, H.S.A., F.A. and H.M.R.; Funding acquisition, M.I., A.A.A. and M.N.A.; Investigation, H.S.A., F.A., S.R., R.M.I. and Z.I.; Methodology, H.S.A., M.I., F.A., H.M.R. and Z.I.; Project administration, M.I.; Resources, T.-u.-H., Rao Muhammad Ikram, A.A.A., M.N.A. and S.A.; Software, Rao Muhammad Ikram, Z.I., T.-u.-H. and S.A.; Supervision, M.I.; Validation, H.S.A. and S.R.; Visualization, S.R. and T.-u.-H.; Writing-original draft, H.M.R., A.A.A. and S.A.; Writing—review \& editing, Mohammed Nasser Alyemeni, T.-u.-H. and S.A. All authors have read and agreed to the published version of the manuscript.

Funding: This research was partially supported by the MNS University of Agriculture, Multan, Pakistan, under the Postgraduate Program. The authors would like to extend their sincere apprecia- 
tion to the Researchers Supporting Project Number (RSP-2020/236), King Saud University, Riyadh, Saudi Arabia.

Institutional Review Board Statement: Not Applicable.

Informed Consent Statement: Not Applicable.

Data Availability Statement: Not Applicable.

Acknowledgments: The authors would like to extend their sincere appreciation to the MNS University of Agriculture, Multan and Central Cotton Research Institute (CCRI), Multan. The authors would like to extend their sincere appreciation to the Researchers Supporting Project Number (RSP2020/236), King Saud University, Riyadh, Saudi Arabia. We are also highly thankful to Azhar khan for English language editing.

Conflicts of Interest: The authors declare no conflict of interest.

\section{References}

1. Latif, M.; Haider, S.S.; Rashid, M.U. Adoption of high efficiency irrigation systems to overcome scarcity of irrigation water in Pakistan. Proc. Pak. Acad. Sci. 2016, 53, 243-252.

2. Annonymous. Economic Survey of Pakistan; Finance Division, Government of Pakistan: Islamabad, Pakistan, 2018.

3. Shareef, M.; Gui, D.; Zeng, F.; Waqas, M.; Zhang, B.; Iqbal, H. Water productivity, growth, and physiological assessment of deficit irrigated cotton on hyperarid desert-oases in northwest China. Agric. Water Manag. 2018, 206, 1-10. [CrossRef]

4. Gu, Z.; Qi, Z.; Ma, L.; Gui, D.; Xu, J.; Fang, Q.; Yuan, S.; Feng, G. Development of an irrigation scheduling software based on model predicted crop water stress. Comput. Electron. Agric. 2017, 143, 208-221. [CrossRef]

5. Ashraf, M.; Rao, M.I.; Salam, H.A.; Bhatti, A.Z. Determining water requirements of major crops in the lower indus basin of Pakistan using drainage type lysimeters. Pak. J. Agric. Sci. 2018, 55, 973-978. [CrossRef]

6. Chapagain, A.K.; Hoekstra, A.Y. The global component of freshwater demand and supply: An assessment of virtual water flows between nations as a result of trade in agricultural and industrial products. Water Int. 2008, 33, 19-32. [CrossRef]

7. Sahito, A.; Baloch, Z.A.; Mahar, A.; Otho, S.A.; Kalhoro, S.A.; Ali, A.; Kalhoro, F.A.; Soomro, R.N.; Ali, F. Effect of water stress on the growth and yield of Cotton crop (Gossypium hirsutum L.). Am. J. Plant Sci. 2015, 6, 1027-1039. [CrossRef]

8. Zhang, H.; Khan, A.; Tan, D.K.Y.; Luo, H. Rational water and nitrogen management improves root growth, increases yield and maintains water use efficiency of cotton under mulch drip irrigation. Front. Plant Sci. 2017, 8, 1-10. [CrossRef]

9. Tsakmakis, I.; Kokkos, N.; Pisinaras, V.; Papaevangelou, V.; Hatzigiannakis, E.; Arampatzis, G.; Gikas, G.D.; Linker, R.; Zoras, S.; Evagelopoulos, V.; et al. Operational Precise Irrigation for Cotton Cultivation through the Coupling of Meteorological and Crop Growth Models. Water Resour. Manag. 2017, 31, 563-580. [CrossRef]

10. Tsakmakis, I.D.; Zoidou, M.; Gikas, G.D.; Sylaios, G.K. Impact of irrigation technologies andstrategies on Cotton water footprint using AquaCrop and CROPWAT models. Environ. Process. 2018, 5, 181-199. [CrossRef]

11. Sarwar, A.; Qureshi, A.S. Water Management in the Indus Basin in Pakistan: Challenges and Opportunities. Mt. Res. Dev. 2011, 31, 252-260.

12. Dagdelen, N.; Basal, H.; Yilmaz, E.; Gurbuz, T.; Akcay, S. Different drip irrigation regimes affect cotton yield, water use efficiency and fiber quality in western Turkey. Agric. Water Manag. 2009, 96, 111-120. [CrossRef]

13. Ahmad, F.; Uddin, S.; Ahmad, N.; Islam, R. Phosphorus-microbes interaction on growth, yield and phosphorus-use efficiency of irrigated cotton. Arch. Agron. Soil Sci. 2013, 59, 341-351. [CrossRef]

14. Iqbal, M.A.; Bodner, G.; Heng, L.K.; Eitzinger, J.; Hassan, A. Assessing yield optimization and water reduction potential for summer-sown and spring-sown maize in Pakistan. Agric. Water Manag. 2010, 97, 731-737. [CrossRef]

15. Imran, M.; Iqbal, M.; Ullah, E.; Šimunek, J. Assessment of actual evapotranspiration and yield of wheat under different irrigation regimes with potassium application Assessment of actual evapotranspiration and yield of wheat under different irrigation regimes with potassium application. Soil Environ. 2015, 34, 156-165.

16. Smith, M.; Allen, R.; Pereira, L. Revised FAO methodology for crop-water requirements. Int. Energy Agency 1998, $29,51-58$.

17. Hussain, G.; Al-Jaloud, A.A.; AI-Shammary, S.F.; Karimulla, S. Effect of saline irrigation on the biomass yield, and the protein, nitrogen, phosphorus, and potassium composition of alfalfa in a pot experiment. J. Plant Nutr. 1995, 18, 2389-2408. [CrossRef]

18. Blake, G.R.; Hartage, K.H. Methods of Soil Analysis, Part 1. Phys. Miner. Methods 1986, 9, 363-375.

19. Saxton, K.E.; Rawls, W.J. Soil Water Characteristic Estimates by Texture and Organic Matter for Hydrologic Solutions. Soil Sci. Soc. Am. J. 2006, 70, 1569-1578. [CrossRef]

20. Grantz, D.A.; Zhang, X.J.; Metheney, P.D.; Grimes, D.W. Indirect measurement of leaf area index in Pima cotton (Gossypium barbadense L.) using a commercial gap inversion method. Agric. For. Meteorol. 1993, 67, 1-12. [CrossRef]

21. Bhagwat, M.A.; Bk, R.; Parmar, P.R.; Ramani, H. Physiological characterization of cotton genotypes (Gossypium herbaceum L.) for salinity at seedling stage. IJCS 2020, 8, 2306-2312.

22. Steel, R.G.D.; Torrie, J.H.; Dicky, D.A. Principles and Procedures of Statistics, 3rd ed.; Approach, A., Ed.; Book Co. Inc.: New York, NY, USA, 1997. 
23. Ünlü, M.; Kanber, R.; Koc, D.L.; Tekin, S. Effects of deficit irrigation on the yield and yield components of drip irrigated cotton in a mediterranean environment. Agric. Water Manag. 2011, 98, 597-605. [CrossRef]

24. Fereres, E.; Soriano, M.A. Deficit irrigation for reducing agricultural water use. J. Exp. Bot. 2007, 58, 147-159. [CrossRef] [PubMed]

25. Ertek, A.; Kanber, R. Effects of different drip irrigation programs on the boll number and shedding percentage and yield of cotton. Agric. Water Manag. 2003, 60, 1-11. [CrossRef]

26. Basal, H.; Dagdelen, N.; Unay, A.; Yilmaz, E. Effects of deficit drip irrigation ratios on cotton (Gossypium hirsutum L.) yield and fibre quality. J. Agron. Crop Sci. 2009, 195, 19-29. [CrossRef]

27. Giday, H.; Fanourakis, D.; Kjaer, K.H.; Fomsgaard, I.S.; Ottosen, C. Threshold response of stomatal closing ability to leaf abscisic acid concentration during growth. J. Exp. Bot. 2014, 65, 4361-4370. [CrossRef]

28. Koubouris, G.; Bouranis, D.; Vogiatzis, E.; Nejad, A.R.; Giday, H.; Tsaniklidis, G.; Ligoxigakis, E.K.; Blazakis, K. Scientia Horticulturae Leaf area estimation by considering leaf dimensions in olive tree. Sci. Hortic. 2018, 240, 440-445. [CrossRef]

29. Wanjura, D.F.; Upchurch, D.R.; Mahan, J.R.; Burke, J.J. Cotton yield and applied water relationships under drip irrigation. Agric. Water Manag. 2002, 55, 217-237. [CrossRef] 